University of Nebraska - Lincoln

DigitalCommons@University of Nebraska - Lincoln

Nebraska Cooperative Fish \& Wildlife Research Nebraska Cooperative Fish \& Wildlife Research Unit -- Staff Publications

2010

\title{
Implications of stunting on morphology of freshwater fishes
}

Christopher J. Chizinski

Texas Tech University, cchizinski2@unl.edu

Kevin L. Pope

University of Nebraska-Lincoln, kpope2@unl.edu

G.R. Wilde

Texas Tech University

R.E. Strauss

Texas Tech University

Follow this and additional works at: https://digitalcommons.unl.edu/ncfwrustaff

Part of the Other Environmental Sciences Commons

Chizinski, Christopher J.; Pope, Kevin L.; Wilde, G.R.; and Strauss, R.E., "Implications of stunting on morphology of freshwater fishes" (2010). Nebraska Cooperative Fish \& Wildlife Research Unit -- Staff Publications. 13.

https://digitalcommons.unl.edu/ncfwrustaff/13

This Article is brought to you for free and open access by the Nebraska Cooperative Fish \& Wildlife Research Unit at DigitalCommons@University of Nebraska - Lincoln. It has been accepted for inclusion in Nebraska Cooperative Fish \& Wildlife Research Unit -- Staff Publications by an authorized administrator of DigitalCommons@University of Nebraska - Lincoln. 


\title{
Implications of stunting on morphology of freshwater fishes
}

\author{
C. J. Chizinski*†, K. L. Popeł, G. R. Wilde§ and R. E. Strauss $§$ \\ *Department of Natural Resources, Texas Tech University, Lubbock, TX 79409, U.S.A., \\ $\$ U S G S$ - Nebraska Cooperative Fish and Wildlife Research Unit, School of Natural \\ Resources, University of Nebraska, Lincoln, NE 68583, U.S.A. and §Department of Biological \\ Sciences, Texas Tech University, Lubbock, TX 79409, U.S.A.
}

(Received 17 April 2008, Accepted 21 October 2009)

\begin{abstract}
The purpose of this study was to assess morphological differences between stunted and non-stunted white perch Morone americana and green sunfish Lepomis cyanellus. Few female M. americana were captured; thus, morphological differences between adult males and juveniles were assessed for M. americana. Similarly, few immature (juvenile) L. cyanellus were captured for the stunted morphotype; thus, male and female morphological differences were assessed for L. cyanellus. Features of the head tended to be relatively larger in stunted fish of both species, whereas the mid-body tended to be relatively larger in non-stunted M. americana, but not in non-stunted L. cyanellus. Adult and juvenile morphology overlapped considerably in non-stunted $M$. americana, but there was a clear distinction between adult and juvenile morphology of stunted M. americana. There was little sexual dimorphism in shape in stunted L. cyanellus, whereas sexual dimorphism was evident in non-stunted L. cyanellus. It appears that selective forces imposed by predation and food limitation may contribute to morphological diversification between stunted and non-stunted fishes.

(C) 2010 The Authors

Journal compilation (C) 2010 The Fisheries Society of the British Isles
\end{abstract}

Key words: body shape; Lepomis cyanellus; Morone americana; morphometry; stunted fishes.

\section{INTRODUCTION}

Stunted populations are frequently observed in fishes (Roff, 1992). Chizinski (2007) defined a stunted population as consisting of individuals that grow slowly and mature early and at a small size, in which growth is restricted by density-dependent mechanisms, and the diminished maximum size is not genetically determined. Several ecological factors, including increased survival from reduced predation and decreased food availability, may influence the development of individuals in stunted populations (Roff, 1992; Ylikarjula et al., 1999; van Kooten et al., 2007). Predation is an important population structuring mechanism, which has a close relationship to prey density and, hence, density-dependent food limitation (Anders, 2001), and which imposes a strong selective pressure at the individual level (Taborsky et al., 2003). When there is sufficient size selective mortality, relatively low density-dependent food limitation,

$\dagger$ Author to whom correspondence should be addressed at present address: Department of Fisheries, Wildlife, and Conservation Biology, University of Minnesota, St Paul, MN 55108, U.S.A. Tel.: +1 612626 4964; fax: +1612625 5299; email: chrischizinski@umn.edu 
and the presence of a size refuge (determined by the interaction of predation risk and prey morphology), life-history theory predicts that fishes should delay reproduction and grow to a larger asymptotic size (Stearns, 1989, 1992; Roff, 1992; Taborsky, 2006). Alternatively, when predation risk is minimal, density-dependent food limitation is sufficiently strong and growth rate of fishes limited, life-history theory predicts early reproduction and a smaller asymptotic size (Stearns, 1989, 1992; Roff, 1992; Taborsky, 2006).

In addition to influencing population structure in fishes, predation has been observed to affect body morphology (Brönmark \& Miner, 1992; Januszkiewicz \& Robinson, 2007). Brönmark \& Miner (1992) observed that in ponds containing gapelimited predators, e.g. pike Esox lucius L., there were low densities of large-sized crucian carp Carassius carassius (L.), whereas in ponds without predators there were high densities of small-sized C. carassius. In the presence of predators, C. carassius were relatively deeper bodied, an adaptive, environmentally induced response to minimize predation risk by gape-limited predators. Morphological responses to predation risk also were described in pumpkinseed Lepomis gibbosus (L.) in response to walleye Sander vitreus (Mitchell) predation (Januszkiewicz \& Robinson, 2007) and in mosquitofish Gambusia affinis (Baird \& Girard), which displayed a shape change that was consistent with faster burst-swim response (Langerhans et al., 2004).

The morphological effects of the interaction between predation and food limitation are less well known. In a series of experiments, Chivers et al. (2008) examined the effects of food availability and predation on the growth and morphology of goldfish Carassius auratus (L.). They observed that food level affected the magnitude of the morphological changes in response to predation. For example, C. auratus under low food availability and in the presence of predation displayed smaller changes in body depth than did $C$. auratus exposed to predation without food limitation. Stunted fishes, compared with their non-stunted conspecifics, would be good subjects to provide further analysis of this interaction. Given the role of predation and food limitation in influencing the development of a stunted population, it is expected that these influences would be manifested in the morphologies of individuals in stunted and non-stunted populations. In non-stunted fishes, it is expected that morphology is largely influenced by predation, whereas in stunted fishes it is expected that morphology is largely influenced by food limitation (Fig. 1). Thus, the purpose of this study was to assess morphological differences between stunted and nonstunted morphotypes of two freshwater fish species that have a propensity to stunt. In addition to assessing morphological differences between the two morphotypes,

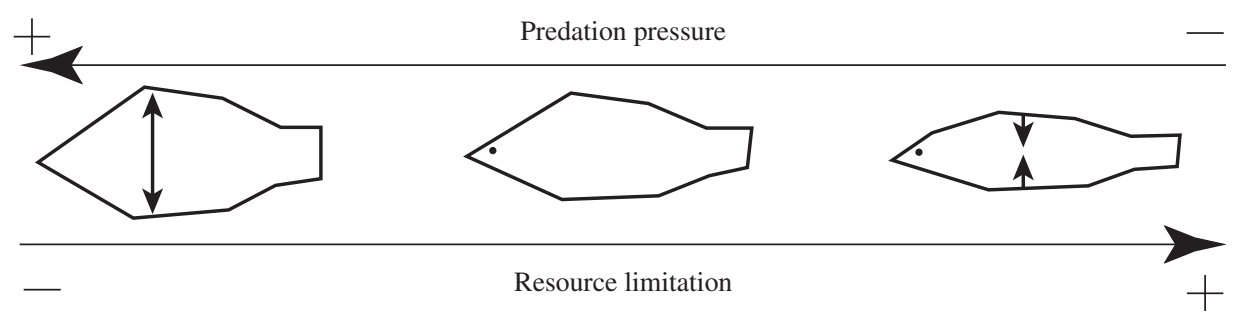

FIG. 1. Conceptualization of the factors associated with stunting and the morphological implications of those factors in fishes. 
differences between juvenile and adult forms and between male and female forms were assessed. Several predictions were made concerning morphological differentiation between stunted and non-stunted fishes: 1) there would be clear differentiation in body form between stunted and non-stunted fishes, 2) due to rapid growth rates in the non-stunted fishes, there would be greater differentiation between juvenile and adult forms than in stunted fishes and 3) energy limitations of stunted fishes would constrain the degree of differentiation among the male and female morphologies. Studying differences in morphological expression among the stunted and non-stunted morphotypes should provide insight into the interaction of predation and food limitation in fishes.

\section{MATERIALS AND METHODS}

\section{STUDY SPECIES}

Morphological assessments of stunted and non-stunted fishes focused on two species that frequently exhibit the stunted morphotype. White perch Morone americana (Gmelin) is a pelagic species native to the east coast of North America (Scott \& Crossman, 1973). Morone americana have invaded many water bodies throughout the U.S.A. and has a propensity to form stunted populations (Hergenrader \& Bliss, 1971; Hergenrader, 1980; Wong, 2002). Green sunfish Lepomis cyanellus Rafinesque is a littoral sunfish found throughout North America (Lever, 1996). Lepomis cyanellus also has a propensity to form stunted populations in water bodies lacking predators (Moyle, 2000). There have been no previous assessments of the morphology of M. americana or L. cyanellus in the primary literature. Chizinski (2007) analysed life-history and demographic variables between two populations of each species, which provided the justification for the stunted and non-stunted designations.

\section{STUDY SITES}

Branched Oak Lake ( $40^{\circ} 58^{\prime} \mathrm{N} ; 96^{\circ} 51^{\prime} \mathrm{W}$ ), a 728 ha flood-control reservoir in Lancaster County, Nebraska, was completed in 1967. This reservoir had a fish community consisting of bluegill Lepomis macrochirus Rafinesque, common carp Cyprinus carpio L., blue catfish Ictalurus furcatus (Valenciennes), channel catfish Ictalurus punctatus (Rafinesque), flathead catfish Pylodictis olivaris (Rafinesque), crappie Pomoxis spp., largemouth bass Micropterus salmoides (Lacépède), palmetto bass Morone saxatilis (Walbaum) $\times$ Morone chrysops (Rafinesque), S. vitreus, gizzard shad Dorosoma cepedianum (Lesueur) and M. americana. All species except $C$. carpio and $D$. cepedianum are potential predators of adult $M$. americana. Since their establishment in Branched Oak Lake (Vrtiska et al., 2003), M. americana steadily increased in abundance ultimately achieving a large, stable but stunted population.

Pawnee Lake $\left(40^{\circ} 50^{\prime} \mathrm{N} ; 96^{\circ} 52^{\prime} \mathrm{W}\right)$, a 299 ha flood-control reservoir in Lancaster County, Nebraska, was completed in 1964. This reservoir is located $14 \mathrm{~km}$ south of Branched Oak Lake. Pawnee Lake had a fish community consisting of C. carpio, I. punctatus, P. olivaris, Pomoxis spp., freshwater drum Aplodinotus grunniens Rafinesque, M. salmoides, M. chrysops, sauger Sander canadensis (Griffith \& Smith), S. vitreus and M. americana. All species except C. carpio and A. grunniens are potential predators of adult M. americana. Since becoming established in Pawnee Lake, M. americana have not become overly abundant, and grow to a larger maximum size than M. americana in Branched Oak Lake (Fig. 2).

Justiceburg Pond $\left(33^{\circ} 00^{\prime} \mathrm{N} ; 101^{\circ} 11^{\prime} \mathrm{W}\right)$ was surrounded by native grasslands on the Texas Tech University Experimental Ranch near Justiceburg, Texas, and had a $0 \cdot 25$ ha surface area and a maximum depth of $3 \mathrm{~m}$. Only L. cyanellus occurred in this pond. A high incidence of cannibalism in adult L. cyanellus was observed in Justiceburg Pond (C. J. Chizinski, unpubl. data). The maximum size of L. cyanellus in Justiceburg Pond (Fig. 2) was similar to typical lengths for this species (Moyle, 2000). 


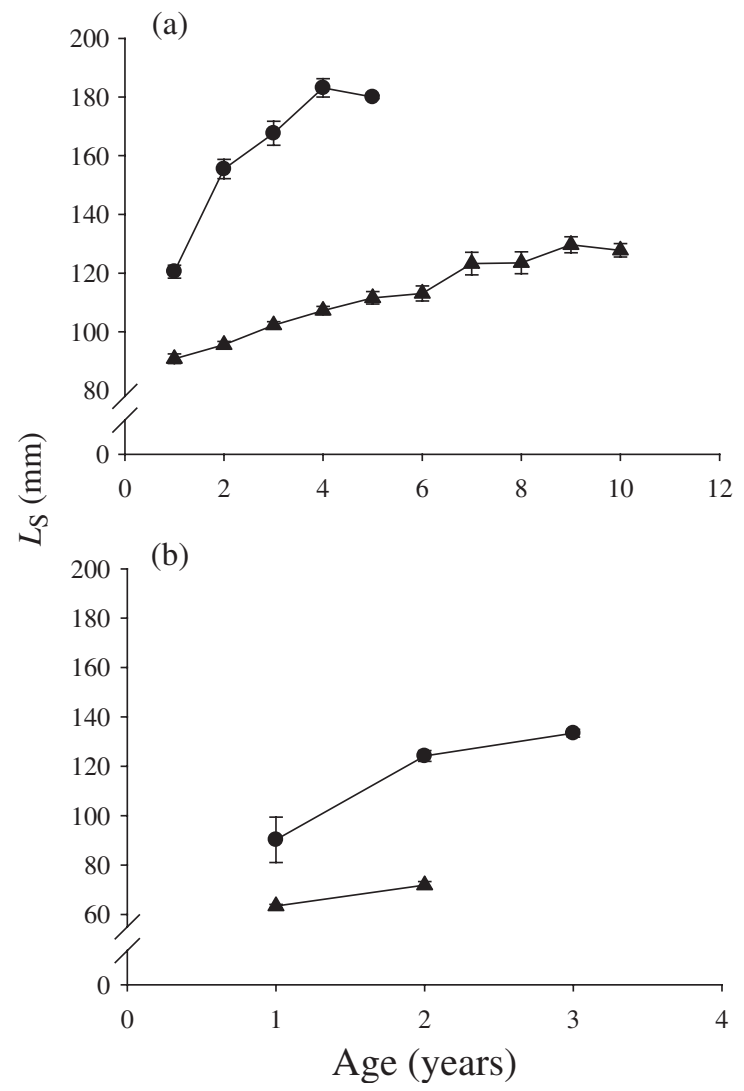

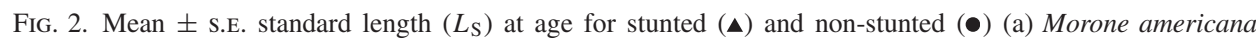
and (b) Lepomis cyanellus sampled during 2006.

Mahon Pond $\left(33^{\circ} 33^{\prime} \mathrm{N} ; 101^{\circ} 55^{\prime} \mathrm{W}\right)$ was surrounded by an urban park in Lubbock, Texas, and had a 0.4 ha surface area and a maximum depth of $2 \mathrm{~m}$. Mahon Pond is located $87 \mathrm{~km}$ north-west of Justiceburg Pond. The fish community of Mahon Pond consisted of black bullhead Ameiurus melas (Rafinesque), C. carpio, C. auratus and L. cyanellus. No evidence of cannibalism for L. cyanellus was observed in Mahon Pond (C. J. Chizinski, unpubl. data) and A. melas were the only potential predator. The Mahon Pond L. cyanellus exhibited decreased growth compared to L. cyanellus from Justiceburg Pond (Fig. 2).

\section{FISH SAMPLING}

Species-specific fish-collection protocols were used because of variation in habitat size and spawning behaviour. Morone americana primarily occupy limnetic habitats and spawn during a brief ( $2-3$ weeks) period, whereas $L$. cyanellus occupy littoral habitats and spawn during a protracted (20-24 weeks) period. Morone americana were collected during April 2006 prior to the onset of spawning, with a Smith-Root 5.0 GPP boat electrofisher (pulsed DC) (www.smith-root.com) from Branched Oak Lake and Pawnee Lake. Lepomis cyanellus were collected at biweekly intervals from March until November 2006 with a Smith-Root backpack shocker and a Smith-Root 5.0 GPP boat electrofisher (pulsed DC) from Justiceberg Pond and Mahon Pond. A lethal dose $\left(1 \mathrm{~g}^{-1}\right)$ of MS-222 was used to euthanize all fishes. Later, fishes were stored on ice until processed in the laboratory. 


\section{MORPHOLOGICAL ANALYSES}

Digital photographs of unpreserved individual fishes were taken in the laboratory and digitized using tpsDig (Rohlf, 2006). Thirteen landmarks corresponding to 25 measurements coincided with major points on the outline of the body and the location of the pectoral fin and midpoint of the eye for M. americana and L. cyanellus (Fig. 3). A set of 25 pair-wise distances among landmarks in the form of a truss (Strauss \& Bookstein, 1982) were used for subsequent morphological analyses. Each fish was categorized based on morphotype and reproductive status (i.e. stunted juvenile, stunted adult, non-stunted juvenile and non-stunted adult) for M. americana and gender (i.e. stunted male, stunted female, non-stunted male and non-stunted female) for L. cyanellus. Gender and reproductive status were determined by macro-inspection of the gonads. Few female M. americana were captured ( $n=16$ for Branched Oak Lake; $n=1$ for Pawnee Lake); thus, female M. americana were omitted from analysis to prevent potential biases caused by sexual dimorphism. Similarly, few immature (juvenile) L. cyanellus were captured for the stunted morphotype ( $n=8$ for Mahon Pond); thus, immature L. cyanellus were omitted from analysis to prevent potential biases caused by sexual maturity.

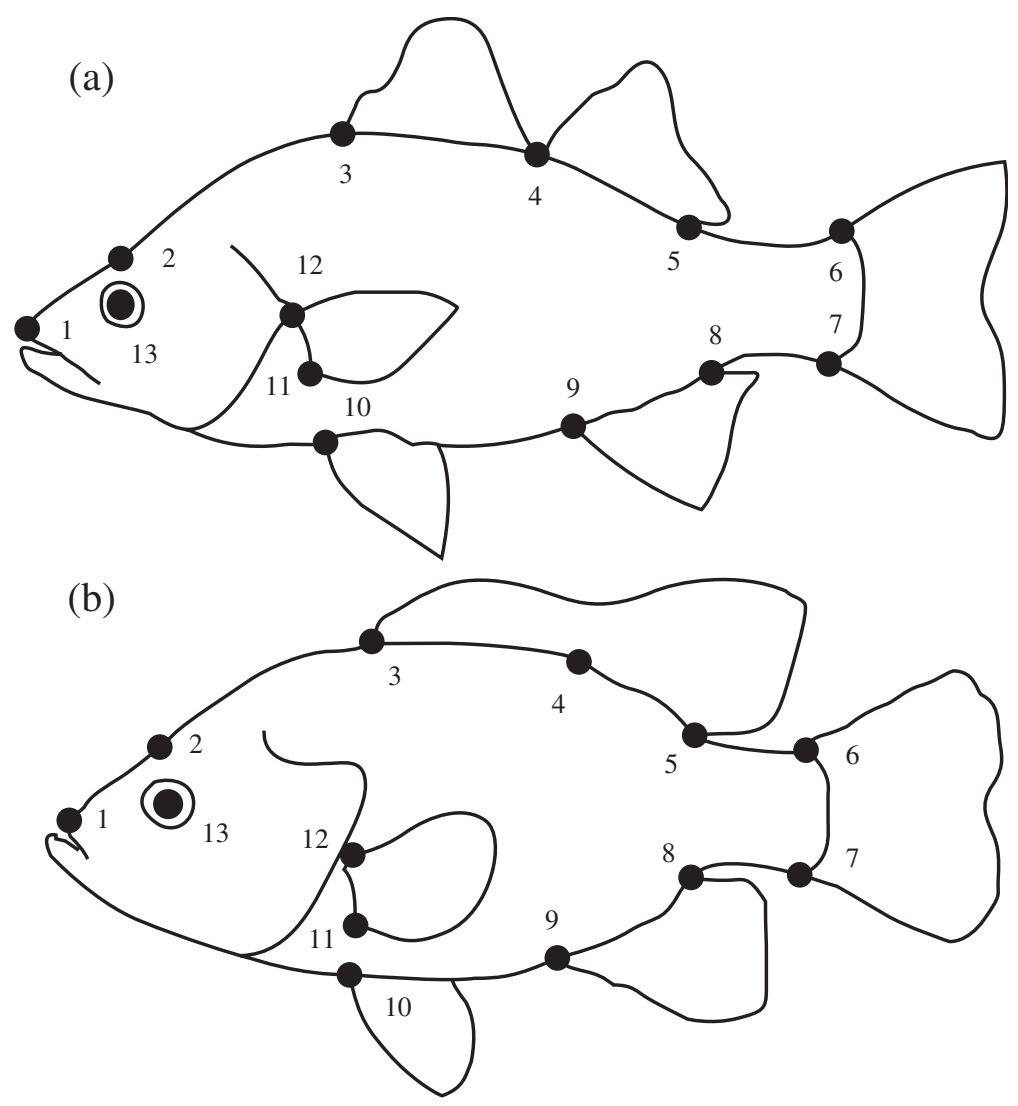

FIG. 3. Landmarks used in the morphological analysis of a (a) Morone americana and (b) Lepomis cyanellus: 1 , snout tip; 2, inflection point on head; 3 , origin of dorsal-fin base; 4, split in dorsal-fin base or origin of soft-ray base; 5 , end of dorsal-fin base; 6 , dorsal origin of caudal-fin base; 7 , ventral origin of caudalfin base; 8 , end of anal-fin base; 9 , origin of anal-fin base; 10 , origin of pelvic-fin base; 11 , end of pectoral-fin base; 12 , origin of pectoral-fin base; 13 , centre of the eye. 
A combination of traditional and geometric morphometric analyses was used to assess differences among a priori group designations. Discriminant function analysis (DFA) on ln-transformed interlandmark distances between co-ordinates was used to assess differences between groups. The size of M. americana in Branched Oak Lake and L. cyanellus in Mahon Pond was, by nature, smaller than that of M. americana in Pawnee Lake and L. cyanellus in Justiceburg Pond, thus requiring correction for size differences. A size-free DFA (Dos Reis et al., 1990) was used. Briefly, this method calculates size-free canonical variables by 1) finding the pooled within-group principal components, 2) regressing characters independently on the first within-group principal component, which characterized size variation from each truss character independently, 3) restoring the group centroids and 4) using the regression residuals in a canonical discriminant analysis. More detail of this process is provided by Strauss (1995). Multivariate analysis of variance (MANOVA) between morphotype, reproductive status or sex, and the associated interaction was used to assess the morphological divergence between groups. Statistical significance of the distance was assessed at $\alpha=0.05$. Jackknifed size-free, ln-transformed morphological characters were used to estimate misclassification error rates. In addition to determining whether shape differences were evident between $a$ priori groupings, loadings (correlations between the size-free distances and the discriminant function scores) identified distinguishing morphological characteristics. It was assumed that variables with an absolute loading $>0.30$ contributed significantly to shape variation. DFA and classification error analysis utilized a Matlab toolbox (www.matlab.com) (Strauss, 2007) in Matlab (v. 6.5).

Consensus plots were used to construct deformation grid plots in tpsSplin (Rohlf, 1994). Deformation grids describe the warping necessary to transform one form into another. If two morphotypes are identical, the output grid will contain straight lines where intersections of all elements are $90^{\circ}$ angles. Deformation between non-stunted juvenile and stunted juvenile, nonstunted adult and stunted adult, stunted juvenile and stunted adult, and non-stunted juvenile and non-stunted adult morphotypes for M. americana; and between non-stunted male and stunted male, non-stunted female and stunted female, stunted male and stunted female, and non-stunted male and non-stunted female morphotypes for L. cyanellus was assessed. Among comparisons between stunted and non-stunted morphotypes, the non-stunted consensus plot was the reference form. Among comparisons between juvenile and adult forms, the juvenile consensus plot was the reference form. Among comparisons between male and female forms, the male consensus plot was the reference form.

\section{RESULTS}

\section{FISH SAMPLING}

A total of 226 M. americana and 248 L. cyanellus was collected for morphological analysis. Among the M. americana, there were 31 stunted juveniles, 60 stunted adults, 22 non-stunted juveniles and 113 non-stunted adults. Among L. cyanellus, there were 59 stunted males, 58 stunted females, 83 non-stunted males and 48 non-stunted females.

\section{MORONE AMERICANA}

\section{Growth comparisons}

Bivariate plots of canonical loadings of morphological distances from the DFA revealed distinct differences in morphology between stunted and non-stunted M. americana. Based on visual inspection of the DFA plot, the separation between stunted and non-stunted morphotypes occurred along the first discriminant axis (Fig. 4), which explained $88.7 \%$ of the variation in morphological distances. Discrimination on this axis was contributed to by 21 measurements, with differences 


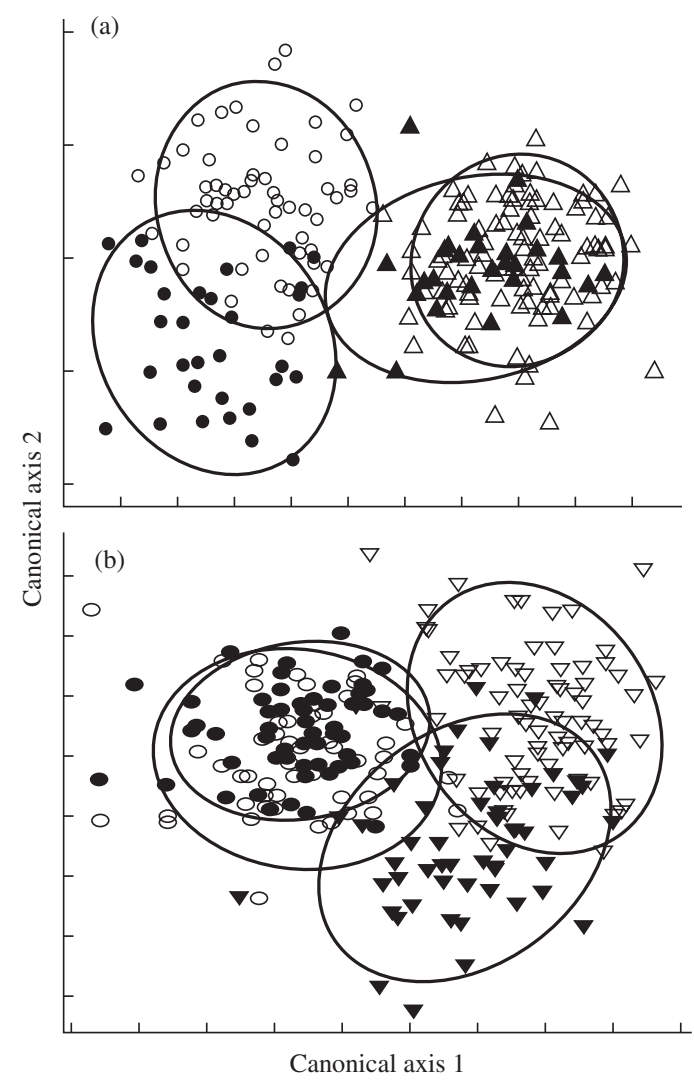

FIG. 4. (a) Canonical roots from discriminant function analysis of Morone americana classified by morphotype and reproductive status: stunted juvenile $(\bullet)$, stunted adult $(\bigcirc)$, non-stunted juvenile $(\boldsymbol{\Delta})$ and non-stunted adult $(\triangle)$. (b) Canonical roots from discriminant function analysis of Lepomis cyanellus classified by morphotype and gender: stunted male $(\circ)$, stunted female $(\bullet)$, non-stunted male $(\nabla)$ and non-stunted female $(\boldsymbol{\nabla})$. Ellipses represent the $95 \%$ CI around the canonical-root centroid for each group.

among the two morphotypes concentrated within three distinct zones: head, preanal body and postanal body. Morphological differences attributable to features in the head and postanal region tended to be greater for stunted $M$. americana than for non-stunted $M$. americana, whereas differences attributable to preanal body tended to be greater for non-stunted M. americana (Fig. 5). The morphological separation among stunted and non-stunted $M$. americana was predominantly attributable to four characteristics: the tip of the snout to the centre of the eye, centre of the eye to the origin of the pectoral-fin base, the split in the dorsal fin to the origin of the anal-fin base and the end of the dorsal-fin base to the end of the anal-fin base (Fig. 5).

There were significant differences (MANOVA, d.f. $=25,198, P<0.001$ ) between stunted and non-stunted M. americana (Table I). Stunted juvenile M. americana and non-stunted adult $M$. americana demonstrated the greatest morphological separation. Few ( $n=4$ of 226) fish were incorrectly reclassified as stunted or non-stunted (Table II). The successful reclassification emphasized the clear morphological discrimination between stunted and non-stunted individuals. 

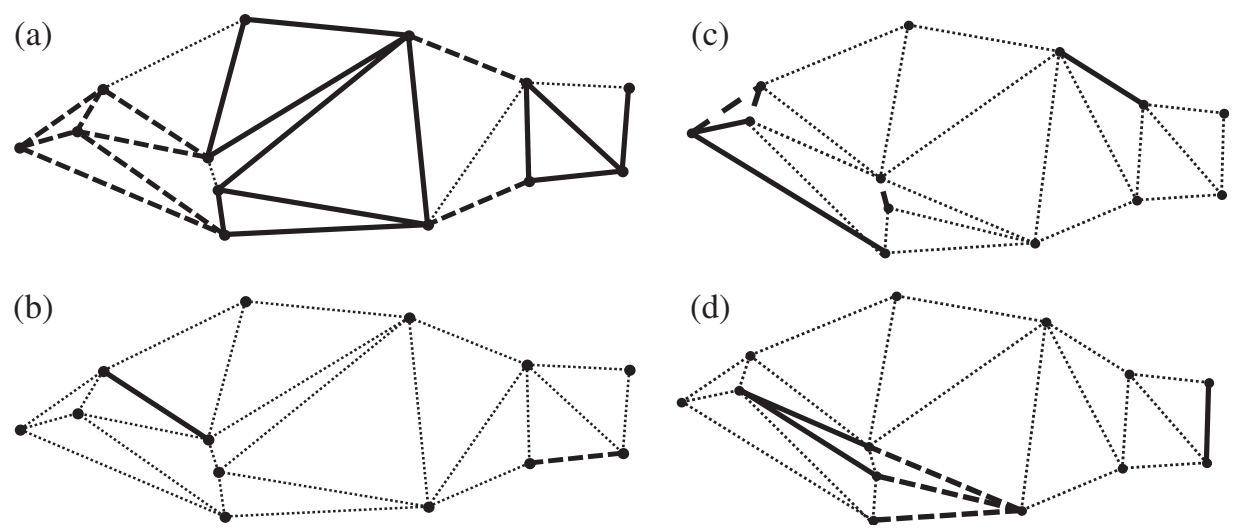

FIG. 5. Significant loadings and landmark co-ordinates between (a) stunted and non-stunted (first discriminant axis) and (b) adult and juvenile (second discriminant axis) Morone americana and co-ordinates between (c) stunted and non-stunted (first discriminant axis) and (d) male and female (second discriminant axis) Lepomis cyanellus. __, morphological distances associated with positive loading values; . . ., morphological distances associated with negative loading values.

\section{Ontogenetic comparisons}

The ability to distinguish between juvenile and adult $M$. americana depended on morphotype and occurred along the second discriminant axis (based on visual inspection of the DFA plot), which explained 8.9\% of the variation (Fig. 4). Juvenile and adult morphologies overlapped considerably for non-stunted $M$. americana, whereas stunted juvenile and adult $M$. americana morphologies showed clearer discrimination. The morphological separation among stunted M. americana was predominantly attributable to two characteristics: the distance from the end of the anal-fin base to the ventral origin of the caudal fin was greater in juvenile M. americana, whereas the distance from inflection point on the head to the origin of the pectoral fin was greater in adult M. americana (Fig. 5).

There were significant differences (MANOVA, d.f. $=25,198 ; P<0.001$ ) between the juvenile and adult $M$. americana (Table I). The associated interaction

TABLE I. Multivariate analysis of variance of ln-transformed distances for Morone americana and Lepomis cyanellus. Population is stunted or non-stunted and maturation is juvenile or adult

\begin{tabular}{lcccrc}
\hline Factor & d.f. (N) & d.f. (D) & Wilks & $F$-value & $P$-value \\
\hline M. americana & & & & & \\
$\begin{array}{l}\text { Population } \\
\text { Maturation }\end{array}$ & 25 & 198 & 0.142 & 47.947 & $<0.001$ \\
$\begin{array}{l}\text { Population } \times \text { maturation } \\
\text { L. cyanellus }\end{array}$ & 25 & 198 & 0.568 & 6.021 & $<0.001$ \\
Population & 25 & 198 & 0.743 & 2.745 & $<0.001$ \\
Sex & 25 & 220 & 0.168 & 43.661 & $<0.001$ \\
Population $\times$ sex & 25 & 220 & 0.643 & 4.889 & $<0.001$ \\
& 25 & 220 & 0.735 & 3.177 & $<0.001$ \\
\hline
\end{tabular}

d.f. (N), numerator d.f.; d.f. (D), denominator d.f. 
TABLE II. Cross-validation (\%) of morphological characteristics for stunted juvenile (SJ), stunted adult (SA), non-stunted juvenile (NJ) and non-stunted adult (NA) Morone americana. Classification error was determined by jackknifed size-free, $\log _{10}$-transformed morphological characteristics

\begin{tabular}{lrrrrrr}
\hline Morphotype & $n$ & SJ & SA & NJ & NA & Error \\
\hline SJ & 31 & $77 \cdot 4$ & $22 \cdot 6$ & $0 \cdot 0$ & 0.0 & $22 \cdot 6$ \\
SA & 60 & $20 \cdot 0$ & $78 \cdot 3$ & $1 \cdot 7$ & $0 \cdot 0$ & $21 \cdot 7$ \\
NJ & 22 & 4.5 & $4 \cdot 5$ & $45 \cdot 5$ & 45.5 & $54 \cdot 5$ \\
NA & 113 & 0.0 & 0.9 & $25 \cdot 7$ & 73.5 & 26.5 \\
\hline
\end{tabular}

$n$, the number of $M$. americana in the sample.

between morphotype and reproductive status was also significant (MANOVA, d.f. = 25, 198, $P<0.001)$. The greatest degree of misclassification occurred between reproductive statuses within a morphotype (Table II). The greatest source of error was incorrect reclassification of non-stunted juvenile $M$. americana as non-stunted adult M. americana.

\section{Shape differences}

Shape deformation was greatest among stunted and non-stunted M. americana (Fig. 6). Among juvenile comparisons, grid deformation primarily was located in the mid-body portion of the stunted morphotype. Shape deformation among adult forms was similar to juvenile forms. Juvenile to adult shape deformation primarily was located within the postanal and head regions for stunted $M$. americana, whereas shape deformation was minimal for non-stunted $M$. americana with deformation located in the postanal region of the adult. The bending energy (i.e. the idealized energy required to deform the reference plot to the target plot) for the deformation was $0 \cdot 015$ between non-stunted juvenile and stunted juvenile $M$. americana, 0.019 between non-stunted adult and stunted adult M. americana, 0.011 between stunted juvenile and stunted adult M. americana, and 0.003 between non-stunted juvenile and non-stunted adult M. americana.

\section{LEPOMIS CYANELLUS}

\section{Growth comparisons}

Bivariate plots of canonical loadings of morphological distances from the DFA revealed distinct differences in morphology between stunted and non-stunted $L$. cyanellus. Based on visual inspection of the DFA plot, separation between the stunted and non-stunted morphotypes occurred along the first discriminant axis (Fig. 4), which explained $76.1 \%$ of the variation in morphological distances. Discrimination on this axis was primarily attributable to six measurements (Fig. 5), mostly concentrated in the head region. The morphological separation among stunted and nonstunted L. cyanellus was predominantly attributable to features in the head (Fig. 5).

There were significant differences (MANOVA, d.f. $=25,220, P<0.001$ ) between stunted and non-stunted L. cyanellus (Table I). Stunted female L. cyanellus and non-stunted male L. cyanellus demonstrated the greatest morphological separation. 
TABLE III. Cross-validation of morphological characteristics for stunted male (SM), stunted female (SF), non-stunted male (NM) and non-stunted female (NF) Lepomis cyanellus. Classification error was determined by jackknifed size-free ln-transformed discriminant analysis of morphological characteristics

\begin{tabular}{llrrrrr}
\hline Morphotype & $n$ & SM & SF & NM & NF & Error \\
\hline SM & 59 & 55.9 & 35.6 & 1.7 & 6.8 & $44 \cdot 1$ \\
SF & 58 & 37.9 & 53.4 & 0 & $8 \cdot 6$ & $46 \cdot 6$ \\
NM & 83 & 6.0 & 1.2 & 79.5 & 13.2 & 20.5 \\
NF & 48 & $4 \cdot 2$ & 8.3 & 20.8 & $66 \cdot 7$ & $33 \cdot 3$ \\
\hline
\end{tabular}

$n$, the number of L. cyanellus in the sample.

Few $(n<10)$ fish were incorrectly reclassified as stunted when non-stunted, and vice versa (Table III). The reclassification emphasized the morphological discrimination between stunted and non-stunted individuals.

\section{Sex comparisons}

Bivariate plots of canonical loadings of morphological distances from the DFA revealed differences between male and female morphology in the non-stunted L. cyanellus, whereas there was less difference between male and female morphology in the stunted L. cyanellus. The separation of male and female L. cyanellus morphology (based on inspection of the DFA plot) was along the second discriminant axis (DF 2), which explained $18.7 \%$ of the variation (Fig. 4). The separation of male and female L. cyanellus was predominantly attributable to five characteristics: distances from the origin of the pelvic-fin base to the origin of the anal-fin base, origin of pectoral-fin base to origin of anal-fin base and end of pectoral-fin base to origin of anal-fin base were greater in females, whereas the distance from the centre of eye to the pectoral-fin base was greater in males (Fig. 5).

There were significant differences (MANOVA, d.f. $=25,220, P<0.001$ ) between male and female L. cyanellus. The associated interaction between morphotype and sex was also significant (MANOVA, d.f. $=25,220, P<0.001$ ). The greatest degree of misclassification occurred between sexes within a morphotype (Table III). The greatest source of error was incorrect reclassification of stunted male L. cyanellus as stunted female L. cyanellus, and stunted female L. cyanellus as stunted male L. cyanellus.

\section{Shape differences}

Shape deformation was the greatest in comparisons of stunted and non-stunted L. cyanellus (Fig. 6). Shape deformation was primarily located in the mouth region and in the depth of the body. Shape deformation among female forms was similar with the male deformation, but not as great. Stunted-female to stunted-male deformation grid indicated very little change in form between the two sexes. Among the non-stunted L. cyanellus, deformation was primarily located in the mouth region and the preanal region. The bending energies for the deformations was 0.013 between non-stunted male and stunted male, 0.090 between non-stunted female and stunted female, 0.001 between stunted male and stunted female and 0.004 between nonstunted male and non-stunted female L. cyanellus. 

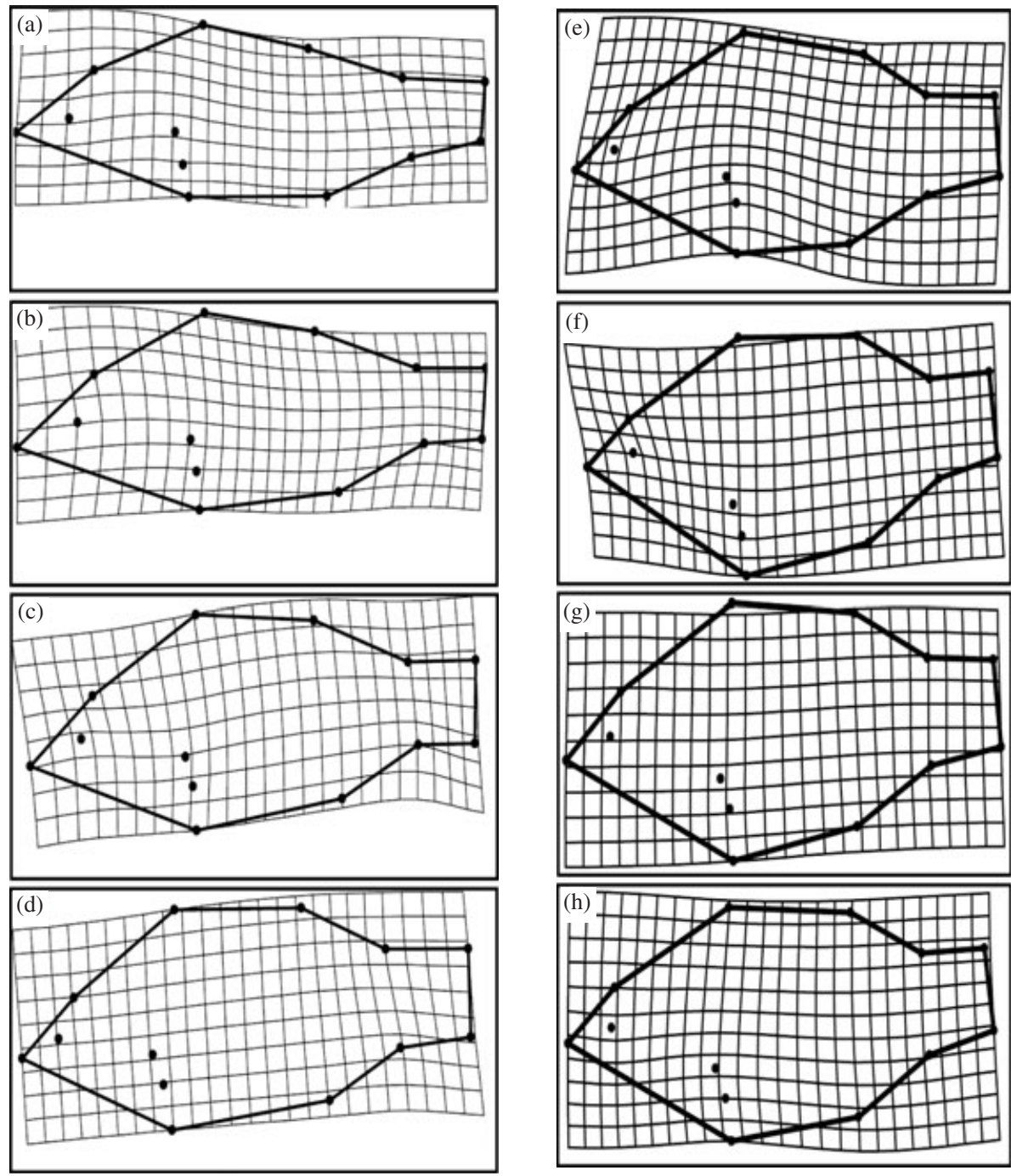

FIG. 6. Deformation grids depicting shape differences between (a) non-stunted juvenile and stunted juvenile, (b) non-stunted adult and stunted adult, (c) stunted juvenile and stunted adult and (d) non-stunted juvenile and non-stunted adult Morone americana. Deformation grids depicting shape differences between (e) non-stunted male and stunted male, (f) non-stunted female and stunted female, (g) stunted male and stunted female and (h) non-stunted male and non-stunted female Lepomis cyanellus. Shape deformation was magnified by $\times 2$ to allow for better visualization of the deformation. Landmark locations were standardized as shown in Fig. 3. If two morphotypes are identical, the output grid will contain straight lines where intersections of all elements are $90^{\circ}$ angles.

\section{DISCUSSION}

Morone americana from Branched Oak and Pawnee reservoirs clearly differed in morphology. Likewise, L. cyanellus from the Justiceburg Pond and Mahon Pond clearly differed in morphology. Despite this consistency, features attributable to 
non-stunted fishes were inconsistent between the two species. Non-stunted $M$. americana displayed a much greater depth and length compared to the stunted M. americana, consistent with predictions and previous research. First, these results suggest that the $M$. americana were under sufficient size-dependent predation from local predators including $P$. olivaris, $M$. salmoides, $S$. canadensis, $S$. vitreus and $M$. chrysops. A deeper body acts to deter predation because predators typically select smaller, more fusiform prey (Wahl \& Stein, 1988) and increases the probability of escape from attack by redirecting predator strikes away from the centre of mass (Webb, 1986). Second, these results provide an indication of the food resources available to the $M$. americana because deeper body forms are energetically costly (Chivers et al., 2008) due to increased hydrodynamic drag (Pettersson \& Brönmark, 1997, 1999). Therefore, morphology of the non-stunted M. americana is consistent with previous studies, which suggest that predation and sufficient food resources prevent the population from becoming stunted in Pawnee Lake.

The deeper and longer body-form features observed in M. americana were not observed in L. cyanellus. The primary morphological feature attributable to nonstunted L. cyanellus was a greater snout length, a morphological adaptation to piscivory (Norton, 1995). There are two potential factors that may account for the disagreement with a priori predictions. Lepomis cyanellus were the only potential fish predators within Justiceburg Pond. Thus, predation may not have been sufficient to select for the deeper body form observed in other sunfishes in response to gapelimited predators (Januszkiewicz \& Robinson, 2007). Second, food limitation may have influenced body form in the non-stunted L. cyanellus. Experiments by Chivers et al. (2008) showed that food limitation affected the amplitude of the response of morphology to predation. Given that the primary mode of predation in the Justiceburg Pond was cannibalism, there may not have been sufficient food resources available for the development of a deeper body form that could be distinguished from stunted L. cyanellus. In water bodies having greater availability of food resources and predation pressure, L. cyanellus may display the deeper body form. Further study is necessary to assess the role of different types of predators and food resources on the morphology of L. cyanellus.

Although there were morphological inconsistencies between the non-stunted M. americana and L. cyanellus, there were morphological consistencies among the stunted individuals. The stunted fishes from both populations had a larger head relative to the rest of their body. A large head in comparison to the rest of the body also has been observed in resource limited perch Perca fluviatilis L. (Olsson et al., 2007). Under food limitation, most energy is allocated to maintenance and little remains for somatic growth (Post \& Parkinson, 2001). Under such conditions, bony structures grow continuously while the rest of the body remains undifferentiated, resulting in the development of fishes with large heads (Olsson et al., 2007). Like the morphology of non-stunted fishes, the morphology of the stunted fishes also is consistent with the suggested mechanisms (i.e. lack of sufficient predation, food limitation and dense populations) that may cause a population to become stunted (Roff, 1992; Ylikarjula et al., 1999).

Morphological differences between juvenile and adult forms of $M$. americana were greater in the stunted morphotype than the non-stunted morphotype. This finding was contrary to the a priori prediction that morphological divergence between juvenile and adult forms would be greater for faster-growing (non-stunted) fish than 
for slower-growing (stunted) fish. The juvenile period was approximately the same for stunted (Branched Oak Lake) and non-stunted (Pawnee Lake) M. americana, whereas longevity was much greater in stunted $M$. americana than in non-stunted M. americana (Chizinski, 2007). The difference in morphology between the juvenile and adult $M$. americana is probably related to plastic allometry (Schlichting \& Pigliucci, 1998). Under normal growing conditions, energy is available for allocation to somatic growth, which has the effect of increasing the somatic tissue at a similar rate to the continuous growth of the bony structures. Thus, allometry of non-stunted M. americana would be relatively isometric, making shape differences less apparent between the juvenile and adult morphologies. Alternatively, stunted fish may allocate less energy to somatic growth because of food limitation, resulting in a body that remains undifferentiated compared to the bony structures in the head, as discussed previously. As stunted fish age, this difference becomes more pronounced, creating a greater morphological divergence between adult and juvenile fish.

The difference in morphology between the male and female forms of L. cyanellus was greater in the non-stunted morphotype than the stunted morphotype. This finding was consistent with the a priori prediction that morphological divergence between adult male and female forms would be greater for faster-growing (nonstunted) fish than for slower-growing (stunted) fish. In general, female L. cyanellus had a relatively deeper preanal area than male L. cyanellus, whereas male L. cyanellus had a relatively longer head region. The deeper preanal region in female $L$. cyanellus is biologically meaningful given the clear relationship of female body size and fecundity in fishes (Roff, 1983, 1984, 1992): females with a larger body cavity can produce a greater number of eggs. The DFA, however, indicates that these morphological differences between male and female L. cyanellus were less distinct in the stunted morphotype, despite female L. cyanellus having similar mass-adjusted fecundities (Chizinski, 2007). This difference in morphology suggests that food limitation, perhaps made more intense by L. cyanellus social behaviour (Hunter, 1963; Gross, 1980; Aday et al., 2006; Cooke et al., 2006), may be reducing the degree of sexual dimorphism in L. cyanellus.

The small size of the male and absence of sexual dimorphism observed in the L. cyanellus may have potential consequences for L. cyanellus social and reproductive biology. Lepomis cyanellus, like other centrarchids, exhibit parental care, which is an energetically expensive behaviour (Cooke et al., 2002, 2006). Lepomis cyanellus are colonial nesters, and males build and defend nests in the littoral zone where female L. cyanellus lay eggs throughout a protracted breeding season (Hunter, 1963). Nesting success of parental males primarily is determined by size and physiological condition (Calow, 1979; Webb, 2002) and decreased size or poor condition of the males may result in lower male reproductive success. Chizinski (2007) observed that stunted L. cyanellus were in poorer condition than non-stunted L. cyanellus, which suggests that stunted L. cyanellus may not have the energetic resources necessary to adequately defend their nests. Aday et al. (2002) observed that parental male L. macrochirus in stunted populations had lower nesting success than male L. macrochirus in non-stunted populations.

Typically, female L. cyanellus select larger males that are perceived to be better nest defenders (Hunter, 1963) but the absence of sexual dimorphism in stunted populations may have implications for mate choice, particularly the long-term consequences of reduced male size. For example, female L. cyanellus may preferentially 
select nesting males that have behaviours (e.g. greater aggressiveness) that allow them to better defend nests against predation. Changes in female mate choice might be observable by comparing recently stunted populations and historically, stunted populations. Female L. cyanellus may preferentially cue on alternative male morphologies as occurs in other species of sunfish. For example, female longear sunfish Lepomis megalotis (Rafinesque) have been shown to preferentially select males with longer opercular flaps (Goddard \& Mathis, 2000). Stunted populations tend to remain stunted until a disturbance reduces the population biomass (e.g. addition of predators and winterkill); thus patterns of female mate choice may become evident through comparison of recently stunted populations and historically stunted populations.

As part of an assessment of cichlid Amphilophus spp. morphology, Parsons et al. (2003) compared traditional truss-based morphometrics with geometric methods and found that both methods are subject to the challenge of isolating shape variation from size variation. In this study of $L$. cyanellus and M. americana, both methods were also used and produced qualitatively similar results. Nevertheless, the traditional method is arguably more meaningful for studying the morphological differences between stunted and non-stunted fishes. These morphological differences probably first develop at small size, perhaps in the larval stage, and propagate throughout the life of the fish and, thus, are confounded with changes in size and allometry. Geometric methods that use thin plate splines to adjust for size differences do so isometrically by adjusting for the centroid size. Isometric scaling is ineffective when it is necessary to account for relative size differences, such as occur between stunted and non-stunted fish of the same species. Alternatively, the traditional method, which uses visual depiction of loading values does adjust for size differences allometrically and provides results that are easily interpretable and biologically relevant.

Although theoretical investigations into the proximate causes of stunting (Ylikarjula et al., 1999) and empirical comparisons of life-history traits between stunted and non-stunted populations have been completed (Chizinski, 2007), morphological implications of stunted populations remain relatively unexplored. Examination of differences among stunted and non-stunted fish morphology provided insight into the interaction of predation and food limitation, two important mechanisms that influence stunted populations. In future studies, a combination of morphometrics and life-history analyses should be continued because of the complimentary information provided by both.

We thank F. C. Sanchez and J. R. Stittle for assistance in the field and laboratory. B. Durham, K. Ostrand and B. Young provided comments on an earlier draft of this manuscript. This work was partially supported by funds from Federal Aid in Sport Fish Restoration, project F-172-R, administered by the Nebraska Game and Parks Commission. The Nebraska Cooperative Fish and Wildlife Research Unit is jointly supported by a cooperative agreement among the U.S. Geological Survey, the Nebraska Game and Parks Commission, the University of Nebraska, the U.S. Fish and Wildlife Service and the Wildlife Management Institute. All animal-use protocols described here meet the guidelines for animal care required of research in the U.S.A., and were approved by the Animal Care and Use Committee of the Texas Tech University and the Institutional Animal Care and Use Committee of the University of Nebraska-Lincoln. Reference to trade names does not imply endorsement by authors or the U.S. Government. 


\section{References}

Aday, D. D., Kush, C. M., Wahl, D. H. \& Philipp, D. P. (2002). The influence of stunted body size on the reproductive ecology of bluegill Lepomis macrochirus. Ecology of Freshwater Fish 11, 190-195.

Aday, D. D., Philipp, D. \& Wahl, D. (2006). Sex-specific life history patterns in bluegill (Lepomis macrochirus): interacting mechanisms influence individual body size. Oecologia 147, 31-38.

Anders, P. (2001). Predator behaviour and prey density: evaluating density-dependent intraspecific interactions on predator functional responses. Journal of Animal Ecology 70, $14-19$.

Brönmark, C. \& Miner, J. G. (1992). Predator-induced phenotypical change in body morphology in crucian carp. Science 258, 1348-1350.

Calow, P. (1979). Adaptive aspects of energy allocation. In Fish Energetics: New Perspectives (Tyler, P. \& Calow, P., eds), pp. 13-32. Bartimore, MD: Johns Hopkins University Press.

Chivers, D., Zhao, X., Brown, G., Marchant, T. \& Ferrari, M. (2008). Predator-induced changes in morphology of a prey fish: the effects of food level and temporal frequency of predation risk. Evolutionary Ecology 22, 561-574.

Chizinski, C. J. (2007). Life-history and morphological variation in stunted and non-stunted fish. PhD Thesis, Texas Tech University, Lubbock, TX, USA.

Cooke, S. J., Philipp, D. P. \& Weatherhead, P. J. (2002). Parental care patterns and energetics of smallmouth bass (Micropterus dolomieu) and largemouth bass (Micropterus salmoides) monitored with activity transmitters. Canadian Journal of Zoology 80, 756-770.

Cooke, S. J., Philipp, D. P., Wahl, D. H. \& Weatherhead, P. J. (2006). Energetics of parental care in six syntopic centrarchid fishes. Oecologia 148, 235-249.

Dos Reis, S., Pessôa, L. \& Strauss, R. (1990). Application of size-free canonical discriminant analysis to studies of geographic differentiation. Revista Brasilerira de Genetic 13, $509-520$.

Goddard, K. \& Mathis, A. (2000). Opercular flaps as sexual ornaments for male longear sunfish (Lepomis megalotis): male condition and male-male competition. Ethology 106, 631-643.

Gross, M. R. (1980). Sexual selection and the evolution of reproductive strategies in sunfishes (Lepomis: Centrarchidae). PhD Thesis, University of Utah, Salt Lake City, UT, USA.

Hergenrader, G. L. (1980). Current distribution and potential for dispersal of white perch (Morone americana) in Nebraska and adjacent waters. American Midland Naturalist 103, 404-406.

Hergenrader, G. L. \& Bliss, Q. P. (1971). The white perch in Nebraska. Transactions of the American Fisheries Society 100, 734-738.

Hunter, J. R. (1963). The reproductive behavior of the green sunfish, Lepomis cyanellus. Zoologica 48, 13-24.

Januszkiewicz, A. J. \& Robinson, B. W. (2007). Divergent walleye (Sander vitreus)-mediated inducible defenses in the centrarchid pumpkinseed sunfish (Lepomis gibbosus). Biological Journal of the Linnean Society 90, 25-36.

van Kooten, T., Persson, L. \& de Roos, A. (2007). Size-dependent mortality induces lifehistory changes mediated through population dynamical feedbacks. American Naturalist 170, 258-270.

Langerhans, R., Layman, C., Shokrollahi, A. \& DeWitt, T. (2004). Predator-driven phenotypic diversification in Gambusia affinis. Evolution 58, 2305-2318.

Lever, C. (1996). Naturalized Fishes of the World. San Diego, CA: Academic Press.

Moyle, P. B. (2000). Inland Fishes of California. Berkeley, CA: University of California Press.

Norton, S. (1995). A functional approach to ecomorphological patterns of feeding in cottid fishes. Environmental Biology of Fishes 44, 61-78.

Olsson, J., Svanbäck, R. \& Eklöv, P. (2007). Effects of resource level and habitat type on behavioral and morphological plasticity in Eurasian perch. Oecologia 152, 48-56. 
Parsons, K. J., Robinson, B. W. \& Hrbek, T. (2003). Getting into shape: an empirical comparison of traditional truss-based morphometric methods with a newer geometric method applied to New World cichlids. Environmental Biology of Fishes 67, 417-431.

Pettersson, L. B. \& Brönmark, C. (1997). Density-dependent costs of an inducible morphological defense in crucian carp. Ecology 78, 1805-1815.

Pettersson, L. B. \& Brönmark, C. (1999). Energetic consequences of an inducible morphological defence in crucian carp. Oecologia 121, 12-18.

Post, J. R. \& Parkinson, E. A. (2001). Energy allocation strategy in young fish: allometry and survival. Ecology 82, 1040-1051.

Roff, D. A. (1983). An allocation model of growth and reproduction in fish. Canadian Journal of Fisheries and Aquatic Sciences 40, 1395-1404.

Roff, D. A. (1984). The evolution of life-history parameters in teleosts. Canadian Journal of Fisheries and Aquatic Sciences 41, 989-1000.

Roff, D. A. (1992). The Evolution of Life Histories: Theory and Analysis. New York, NY: Chapman \& Hall.

Schlichting, C. \& Pigliucci, M. (1998). Phenotypic Evolution: a Reaction Norm Perspective. Sunderland, MA: Sinauer Associates.

Scott, W. B. \& Crossman, E. J. (1973). Freshwater fishes of Canada. Bulletin of the Fisheries Research Board of Canada 184.

Stearns, S. C. (1989). Trade-offs in life-history evolution. Functional Ecology 3, 259-268.

Stearns, S. C. (1992). The Evolution of Life Histories. New York, NY: Oxford University Press.

Strauss, R. E. (1995). Metamorphic growth-gradient changes in the South American loricariid catfishes Loricariichthys maculatus and Pseudohemiodon laticeps. Studies on Neotropical Fauna and Environment 30, 177-191.

Strauss, R. E. \& Bookstein, F. L. (1982). The truss: body form reconstructions in morphometrics. Systematic Zoology 31, 113-135.

Taborsky, B. (2006). The influence of juvenile and adult environments on life-history trajectories. Proceedings of the Royal Society B 273, 741-750.

Taborsky, B., Dieckmann, U. \& Heino, M. (2003). Unexpected discontinuities in life-history evolution under size-dependent mortality. Philosophical Transactions of the Royal Society $B$ 270, 713-721.

Vrtiska, L. A., Jr., Peters, E. J. \& Porath, M. T. (2003). Flathead catfish habitat use and predation on a stunted white perch population in Branched Oak Reservoir, Nebraska. Journal of Freshwater Ecology 18, 605-613.

Wahl, D. H. \& Stein, R. A. (1988). Selective predation by three esocids: the role of prey behavior and morphology. Transactions of the American Fisheries Society 117, $142-151$.

Webb, J. (2002). A theoretical analysis of the energetic costs and consequences of parental care decisions. Philosophical Transactions of the Royal Society B 357, 331-340.

Webb, P. W. (1986). Effect of body form and response threshold on the vulnerability of four species of teleost prey attacked by largemouth bass (Micropterus salmoides). Canadian Journal of Fisheries and Aquatic Sciences 43, 763-771.

Wong, R. K. (2002). White perch expansion and life history within a southern reservoir. MSc. Thesis, North Carolina State University, Raleigh, NC, USA.

Ylikarjula, J., Heino, M. \& Dieckmann, U. (1999). Ecology and adaptation of stunted growth in fish. Evolutionary Ecology 13, 433-453.

\section{Electronic References}

Rohlf, F. J. (1994). tpsSplin 1.2. Available at http://life.bio.sunysb.edu/morph/

Rohlf, F. J. (2006). tpsDig v 2.10. Available at http://life.bio.sunysb.edu/morph/

Strauss, R. E. (2007). Matlab Toolbox. Available at http://www.biol.ttu.edu/Strauss/Matlab/ matlab.htm 